\title{
Quality of Life of Families of Early Aged Children with Disabilities
}

\author{
Špela Golubović \\ University of Novi Sad \\ spela.golubovic@mf.uns.ac.rs \\ Jasna Maksimović \\ University of Kragujevac \\ jasnamaximovic@gmail.com \\ Jovana Uzelac \\ University of Novi Sad \\ jovanauzelac123@gmail.com

\section{Sandra Glamočak \\ University of Novi Sad \\ sandra97glamocak@gmail.com}

\begin{abstract}
Family is a primary social community that directs and encourages development of a child, shapes the child's personality, directs its participation in the environment whereas the functioning of a family has a significant impact on the quality of life of all its members. Starting from the point that raising a child with developmental disabilities is a serious challenge for parents that requires greater involvement and increased child care, the aim of this research was to examine to what extent the presence of disability in a child affects the quality of life of the family. As the predictor of family life quality, we highlighted the intensity of problems in the child's behaviour (physical, emotional, social and behaviour in the kindergarten). The survey was conducted on a sample of 81 parents of children in early age ( $44.4 \%$ of parents with children with disabilities and $55.6 \%$ with typical developed children. The parents' opinion on the intensity of the behavioural problems and impact of the chronic condition of the child on the functioning of their families was obtained by the PedsQL generic scale questionnaire - the family impact module. The research confirmed that the presence of disabilities and child behaviour problems certainly affect the functioning of the family and that the quality of life of these families differs considerably compared to the ones with typical developed children.
\end{abstract}

Keywords: family, quality of life of the family, parents of children with disabilities, a child with disabilities, typically developed children

\section{Introduction}

According to sociological system theory, family is most often defined as a dynamic, interdependent and target-oriented system, making an impact on 
the environment and receiving a reverse impact from it (Mugno et al. 2007). It represents primary social environment that shapes the child's personality and directs his/her participation in the environment, but also vice versa - the child inevitably affects everyday life and participation of other family members (McConnell, Savage, and Breitkreuz 2006). Establishing sense of security, development of speech, skills and abilities, attitudes, beliefs and values are just some of the influences family has over a child. At the same time, styles of life, authority and relationships among family members, the size of a family and many other factors are considered to be such great sources of difference that it is very difficult to find a common denominator for a community such is a family (Ristić-Stojković 2016; Hrnjica 2011). It represents an influential and important factor of social functioning because it refers to the primary small group in which emotional relationships are intense, interaction is longlasting and diverse, and the mutual dependence among members is high.

Despite the fact that every family is special for it forms an original system with its specific rules and modes of coexistence (Juhásová 2015, 3383), it is true for every family that all of its members are interconnected, and as a rule, what affects one of them, also reflects on the whole family system. The functioning of the family itself is reflected and has a positive or a negative impact on the quality of life of all its members (Smith-Bird and Turnbull 2005).

The quality of life can be seen and defined in many ways, though it is most often defined as an individual experience of satisfaction with all aspects of life, that is, the perception of one's own well-being and life satisfaction. This sociological dimension includes physical, social, economic and psychological well-being, as well as a sense of positive social involvement and the ability to realize one's own potentials (Araujo de Melo et al. 2012; Mugno et al. 2007; Park et al. 2003; Waters et al. 2005). The concept of quality of life includes numerous aspects of life at the present moment, as well as previous experiences of a person, so the quality of family life is a natural continuation of work on the individual quality of life (Poston et al. 2003). In order to ensure that the quality of family life is considered satisfactory, needs of a family need to be satisfied; family members should enjoy their life together and have the opportunity to deal with matters that are important to them (Park et al. 2003, 368). Health is certainly one of the factors of quality of life that plays a significant role, and any presence of illness or disability is a limiting factor in the fulfilment of the needs of an individual and his/her family members.

\section{Family and parenthood of children with disabilities}

Although every birth of a child extraordinarily mobilizes a family and has a significant impact on parents and other family members, the birth of a child 
with disabilities represents a serious new reality and has a strong stressful influence (Juhásová 2015; Hrnjica 2011). After a stressful situation and an initial shock that undoubtedly occurs upon knowledge of a diagnosis indicating that the child will have serious disorders in growth and development (Emerson 2003; Florian and Findler 2001; Hedderly, Baird and McConachie 2003; Osmančević-Katkić, Lang-Morović and Kovačić 2017; Rentinck et al. 2009) parents enter the phase of adaptation to the new situation that requires the reconstruction of both family and their personal identities. This adaptation implies solving the task of cognitive and emotional diagnosis procession, its implications on further development of a child and the future functioning of the family (Axelsson, Granlund, and Wilder 2013; Barnett et al. 2003). Research conducted in our country suggests relatively high percentage of parents who are unresolved towards diagnosis (Mihić et al. 2016). They did not fully understand and accepted the factual situation. A parent who has accepted a diagnosis with all its implications can be realistic in relation to the child's health and abilities. He/she can recognize the possibilities and limitations of the child, successfully align his parental role with the child's needs and be sensitive towards the needs of the child. If the parent has not resolved his/her dilemmas in relation to the child's diagnosis, he/she makes no progress over time, but focuses on the moment of learning and is emotionally overwhelmed, which leads to unrealistic expectations of the child and lower quality of care (Marvin and Pianta 1996 in Rajić and Mihić 2015, 139).

Whether and to what extent, the experience of the birth of a child with developmental disability will be traumatic, and the way the next phase in establishing relationship with the child will be resolved, depend on a number of factors. The most important factors affecting the acceptance of the newly emerging situation are the 'type and severity of developmental disorder, emotional characteristics of the child (calmness, irritability), emotional stability of family members, the quality of interpersonal relations within the family, motivation of the family to overcome difficulties, etc.' (Hrnjica 2011, 72). This points to the fact that being a parent of a child with developmental disabilities is significantly more demanding compared to the parenting of children of typical development since it is burdened with factors such are specific needs of the child, increased demands related to additional health care, as well as taking responsibility for making important decisions concerning the future of the child (Brown et al. 2003).

Both our and worldwide experiences and research suggest that the birth of a child with developmental disability often changes the current functioning and quality of life of all family members. The influence of developmental disturbance on various aspects of family life - household, recreation, social- 
ization, feelings, own identity, education and professional development, etc., are described (Price et al. 2000). Demands that arise due to such impact may require significant financial costs and complicate other aspects of life.

Apart from the initial request for reorganization and strengthening of the family relationships structure, the family is faced with numerous demands for increased childcare and a number of aggravating circumstances in relation to these requirements. Parents are constantly confronted with the needs of the child, which are often unclear and far different from the needs of children of typical development; therefore, they are not always sure how to satisfy them. The characteristics of developmental disorder, such as communication difficulties, significantly hampered motor development, lack of feedback from the child, reduced ability to interpret social signals, etc., often interfere with the child's signal behaviour and parents' response, leading to reduced sensitivity and a lesser chance of adequate responses (Van ljzdendoorn et al. 2007). Parents often invest all their resources in the treatment of the child, but ignore or insufficiently encourage the child's psychosocial development. Many of them, due to lack of information on who could help them, often feel completely helpless. Also, many families with children with serious disabilities and developmental disorders are impoverished for additional costs and endangered by limited employment opportunities (Juhásová 2015; McConnell, Savage, and Breitkreuz 2014).

All this is associated with an increased level of stress, mental health disorder, low self-esteem, difficulties in physical functioning, chronic fatigue and exhaustion of parents (Milićević 2015; Gardiner and larocci 2012). This leads to the conclusion that the quality of family life goes beyond the needs of a child with developmental disability and summarizes the needs of all family members as well as the strong sides of the family functioning (Smith-Bird and Turnbull 2005). That the presence of disturbance in development is not the only factor determining the quality of family life. However, studies show that families of children with developmental disabilities tend (Gardiner and larocci 2012)

\section{Research Methodology}

The quality of family life can be observed in relation to an individual and in relation to all family members (Milićević 2015). The aim of this survey is to determine whether the presence of a disability in a child affects the quality of life of its family, and in which domains it differs from the same in the families with typical developed children. The research focus has been directed to perception of certain problems in the functioning of such children by their 
Table 1 Examples of Behavioural Problems' Indicators (PEDsQL Generic Scale)

\begin{tabular}{ll}
\hline Domain & Indicator \\
\hline Physical & Participation in an active game or physical activity \\
& Help with collecting toys \\
& Feeling pain \\
& Low energy level \\
\hline Emotional & Feeling fear \\
functioning & Sleep difficulties \\
& Feeling anger \\
\hline Social & Other kids do not want to play with your child \\
functioning & Unable to do things other kids of his/her age can \\
\hline Functioning & Does not perform same activities in the kindergarten as his/her peers \\
in a kindergarten & Absence from the kindergarten for not feeling well \\
& Absence from the kindergarten to go to the doctor's or hospital \\
\hline
\end{tabular}

parents, which can serve as one of the indicators of the quality of family life. Problems can be manifested as problems in the physical, social or emotional functioning of a child. We started from the assumption that the problems associated with certain areas of child functioning would be significantly more present in children with disabilities.

The research was conducted through an on-line survey that was forwarded to parents' associations of children with disabilities as well as parents of typical children who attend the kindergarten. Parents' opinion on the impact of the disabilities of the child on the functioning of their families was obtained by the PEDsQL generic scale questionnaire - the family impact module. PED$S Q L$ is a generic instrument that measures the quality of life of a wide population in relation to the health of children aged 2 to 18 . It is used both for clinical and research purposes. The survey used part of the questionnaires filled in by parents of children aged 2 to 4 . It consists of 23 items and assesses the quality of life through 4 domains: physical functioning (8 items); emotional functioning ( 5 items); social functioning ( 5 items); functioning in kindergarten (5 items). Answers to questions range from o to 4 , where o refers to behaviours that never pose a problem to a child, 1 - almost never, 2 - sometimes, 3 often, while 4 refers to behaviours that almost always represent a problem. The questions relate to behavioural problems that have occurred over the past month compared to the time of the survey. Table 1 presents some of the behavioural indicators that affect the quality of life of the whole family.

The survey sample consisted of 81 respondents ( $44.4 \%$ of parents of children with disabilities, $55.6 \%$ of parents of children with typical development). 
Table 2 Respondents' Demographic Data

\begin{tabular}{llrr}
\hline Item & Category & $f$ & $f \%$ \\
\hline Gender of a child & Male & 43 & 53.09 \\
& Female & 38 & 46.93 \\
Presence of a developmental disorder & Yes & 36 & 44.40 \\
& No & 45 & 55.60 \\
\hline Parents' education level & Primary school & $2(1.7)$ & 0 \\
& Secondary school & $28(23.5)$ & $35(29.4)$ \\
& High school - college & $12(10.1)$ & $11(9.2)$ \\
& Higher school - university & $34(28.6)$ & $29(24.4)$ \\
\hline Parents live in & marital community & 63 & 77.78 \\
& extramarital community & 13 & 16.05 \\
& divorced & 2 & 2.47 \\
& single parents & 3 & 3.70 \\
\hline
\end{tabular}

The sample is dominated by female respondents, i.e. the answers were mostly given by mothers of children aged 2 to 4 attending a pre-school institution. According to the data collected from parents, most children suffered from autism, speech or language disorder, developmental delay, cerebral palsy, or other physical disorder. The demographic data of the respondents are presented in Table 2.

In data processing, methods and procedures from the descriptive statistics framework, as well as from the domain of locking statistics - $t$-test, were used.

\section{Research Results and Discussion}

The quality of life of a family of children with disabilities can be viewed through different indicators such are: 'factors related to the child - the degree of child's disability and the intensity of manifestation of problems in his/her behaviour; financial situation of the family, family relations, social status of all family members, adequacy of services provided, etc.' (Milićević 2015, 39). As in some other studies (Davis and Gavidia-Payne 2009), our research also singled out intensity of manifestation of behavioural problems in a child as a predictor of the quality of family life. The assessment includes the frequency of certain behaviour patterns in the area of emotional, physical, social and behaviour in the kindergarten, as well as the intensity of these behaviours (behaviour patterns are shown in table 1). The summary results of the research are shown in Table 3.

By analysing summarized scores, a statistically significant difference $(p<$ 0.05 ) was found on all the subscales in the quality of life of families of children 
Table 3 Differences between Examined Groups

\begin{tabular}{lllrrrr}
\hline Domains & $(1)$ & $(2)$ & $(3)$ & $(4)$ & $t$ & $p$ \\
\hline Physical functioning & Yes & 36 & 26.97 & 25.79 & 3.25 & 0.00 \\
& No & 45 & 14.80 & 5.14 & & \\
\hline Emotional functioning & Yes & 36 & 12.08 & 3.13 & 2.22 & 0.02 \\
& No & 45 & 11.07 & 3.00 & & \\
\hline Social functioning & Yes & 36 & 27.54 & 5.90 & 2.93 & 0.00 \\
& No & 45 & 20.00 & 6.40 & & \\
\hline Functioning in a kindergarten & Yes & 32 & 12.09 & 6.00 & 2.60 & 0.01 \\
& No & 43 & 8.60 & 5.56 & & \\
\hline
\end{tabular}

Notes Column headings are as follows: (1) the presence of a disability in a child, (2) number of respondents, (3) average value, (4) standard deviation.

with disabilities in relation to the families of typical children. By reviewing the obtained average summation scores of each individual domain, one can see that the domain of emotional functioning was rated best in children with developmental disorders (average value 12.08), while the domain of social functioning is rated the worst (average value 27.54). In the group of typical developed children the domain of functioning in the kindergarten was rated best (average value 8.6), while the domain of social functioning was rated the worst (average value 20).

The results obtained in the field of emotional functioning of children with developmental disorders indicate that these children have least problems with expressing negative emotions such as anger, fear, sadness, as well as with sleep. This can lead us to conclude that families of children with developmental disabilities are functional and caring, since the presence of difficulties in emotional functioning often reflects inadequate care, nursing or traumatisation within the family (Mitić, Radojević, and Piper 2011), and that this domain does not significantly affect the quality of family life.

Mitić and associates state that 'autistic and children with other perverting and developmental difficulties can manifest disinterest or fear, retreat from peers and are often also victims of peer violence' (Mitić, Radojević, and Piper 2011, 122). The results of our research, in the domain of social functioning, show that children with disabilities at an early age have significant difficulties in relation to the expected indicators of development (a child cannot do things like other children of his/her age and has difficulty in keeping pace with other children) or in relation to peers (other kids tease him/her; other kids do not want to play with the child). This fact can significantly reduce family interactions as well as ordinary family activities that might become 
complicated or impossible. Similarly, parents can be concerned about the safety of their child in the park or at the playground and whether other children relate to their child friendly or in a brutal manner (McConnell et al. 2014; Hrnjica 2011). All this affects the quality of family life as it requires additional engagement and development of new parental skills that are not involved in the corpus of standard competences related to the parentage of a typical child.

Difficulties the child has in physical behaviour (uncontrollable, inappropriate and non-directional movements) at the age of up to 4, may be related to the lag in physical and/or mental development (Mitić 2011) and could lead to reduced participation in active games or physical activity, which also considerably undermines the dynamics of family relationships. The research of Mainmer et al. (2007) shows that physical functioning as an indicator of the quality of life is closely related to the type and severity of a disorder that is present in a child. The results show that children with diagnosed cerebral palsy have the worst scores in this domain (Maimner et al. 2007; Milićev and Nedović 2017; Waters et al. 2005). In other studies, we find somewhat different results, thus according to the research of Škrbić et al. (2011), which included children with hearing disorders, their quality of life was equally impaired in all domains (Škrbić et al. 2011).

Within the domain of functioning of a child in a kindergarten, parents indicate that children with developmental disabilities also have significantly more problems than their typical peers (they do not perform the same activities in kindergarten as their peers; they are absent from the kindergarten due to going to a doctor or hospital, etc.). The demands placed on the family in this domain are not small, they can greatly undermine and jeopardize its functioning (Mitić 2011) since parents are often deprived of the pre-school institution services due to evident problems their child has. Findings from some studies (Davis and Gavidia-Payne 2009; McConnell et al. 2014) show that the quality of family life is related to the availability of educational and culturally relevant resources rather than internal, individual or family factors. Regarding the quality of family life, strengthening social relationships and improving financial issues might be more important than modification of the child's behaviour.

\section{Conclusion}

The research we conducted in order to determine whether the presence of a disability in a child affects the quality of life of its family is based on two hypotheses. The first, which refers to the fact that the quality of life of fami- 
lies of children with developmental disabilities is significantly different from the same in the families with typical children, has been confirmed. The second one, referring to the fact that the quality of life of families of children with developmental disabilities is disturbed more in the domain of emotional and social than physical functioning, has been partly confirmed, since social functioning is truly poorly assessed, but in the emotional functioning we obtained diametrically opposite results.

The results we obtained in our study, as well as theoretical insight into the problem of the research, indicate that it is necessary to recognize risk factors when selecting and planning social activities aimed at empowering the family of a child with developmental disability and then promote measures that support and improve the quality of life of such family. Supporting families of early aged children with disabilities is important potential for development of inclusive society and leads to preservation of the family's capacity, given that the family represents primary and, at the same time, crucial social community.

\section{References}

Araujo de Melo, E. L., M. Badia Corbella, M. Begona Orgaz Baz, M. A. Verdugo, M. A. Alonso, B. Arias Martinez, M. Gomez-Vela, and A. M. Ullan. 2012. 'Quality of Life in Children and Adolescents with Cerebral Palsy.' Revista Brasileiraem Promocao da Saude 25 (4): 426-434.

Axelsson, A. K., M. Granlund, and J. Wilder. 2013. 'Engagement in Family Activities: A Quantitative, Comparative Study of Children with Profound Intellectual and Multiple Disabilities and Children with Typical Development.' Child: Care, Health and Development 39 (4): 523-534.

Barnett, D., M. Clements, M. Kaplan-Estrin and J. Fialka. 2003. 'Building New Dreams: Supporting Parents' Adaptation to Their Child with Special Needs.' Infants and Young Children 16 (3): 184-200.

Brown, I., S. Anand, W. A. Fung, B. Isaacs, and N. Baum. 2003. 'Family Quality of Life: Canadian Results from an International Study.' Journal of Developmental and Physical Disabilities 15 (3): 207-230.

Davis, K., and S. Gavidia-Payne. 2009. 'The Impact of Child, Family, and Professional Support Characteristics on the Quality of Life in Families of Young Children with Disabilities.' Journal of Intellectual and Developmental Disability 34 (2): 153-162.

Emerson, E. 2003. 'Mothers of Children and Adolescents with Intellectual Disability: Social and Economic Situation, Mental Health Status, and the SelfAssessed Social and Psychological Impact of the Child's Difficulties.' Journal of Intellectual Disability Research 47 (1): 385-399.

Florian, V., and L. Findler. 2001. 'Mental Health and Marital Adaptation among 
Mothers of Children with Cerebral Palsy.' American Journal of Orthopsychiatry 71 (3): 358-367.

Gardiner, E., and G. Iarocci. 2012. 'Unhappy (and Happy) in Their Own Way: A Developmental Psychopathology Perspective on Quality of Life for Families Living with Developmental Disability with and without Autism.' Research in Developmental Disabilities 33 (6): 2177-2192.

Hedderly, T., G. Baird, and H. McConachie. 2003. 'Parental Reaction to Disability.' Current Paediatrics 13 (1): 30-35.

Hrnjica, S. 2011. 'Roditeljstvo dece sa ometenošću: izazovi i teškoće u njegovoj realizacijji.' In Deca sa smetnjama u razvoju, edited by M. Mitić, 72-77. Beograd: Familija.

Juhásová, A. 2015. 'Comparison of Quality of Life of Families with Children with Disability and Families with Children without Disability.' Procedia: Social and Behavioral Sciences 174:3378-3384.

Maimner, A., M. Shevell, P. Rosenbaum, M. Law, and C. Poulin. 2007. 'Determinants of Life Quality in School-Age Children with Cerebral Palsy.' The Journal of Pediatrics 151 (5): 470-475.

Marvin, R. S., and R. C. Pianta. 1996. 'Mothers' Reaction to Their Child's Diagnosis: Relations with Security of Attachment.' Journal of Clinical Child Psychology 25:436-443.

Mihić, I., M. Rajić, T. Krstić, S. Divljan, and N. Lukić. 2016. '»Našapriča« - program podrške deci sa smetnjama u razvoju: primer dobre prakse u predškolskim ustanovama.' Specijalna edukacija i rehabilitacija 15 (4): 477-498.

Milićević, M. 2015. 'Kvalitet života porodica sa detetom sa ometenošću.' Beogradska defektološka škola 2 (2): 39-60.

Milićev, M., and G. Nedović. 2017. 'Povezanost porodičnog kvaliteta života i participacije u porodičnim aktivnostima dece s cerebralnom paralizom i dece tipičnog razvoja.' Beogradska defektološka škola 23 (3), 41-64.

Mitić, M. 2011. 'Porodica, roditelji i roditeljstvo.' In Deca sa smetnjama u razvoju, edited by M. Mitić, 56-65. Beograd: Familija.

Mitić, M., B. Radojević, and B. Piper. 2011. 'Od procene do donošenja odluka.' In Deca sa smetnjama u razvoju, edited by M. Mitić, 116-122. Beograd: Familija.

McConnell, D., A. Savage, and R. Breitkreuz. 2014. 'Resilience in Families Raising Children with Disabilities and Behavior Problems.' Research in Developmental Disabilities 35 (4): 833-848.

Mugno, D., L. Ruta, V. Genitori D'Arrigo, and L. Mazone. 2007. 'Impairment of Quality of Life in Parents of Children and Adolescents with Pervasive Developmental Disorder.' Health Qual Life Outcomes 5 (22): 1-9.

Osmančević Katkić, L., M. Lang Morović, and E. Kovačić. 2017. 'Parenting Stress and a Sense of Competence in Mothers of Children with and without Developmental Disabilities.' Hrvatska revija za rehabilitacijska istraživanja 53 (Supplement): 63-76. 
Park, J., L. Hoffman, J. Marquis, A. P. Turnbull, D. Poston, H. Mannan, and L. L. Nelson. 2003. 'Toward Assessing Family Outcomes of Service Delivery: Validation of a Family Quality of Life Survey.' Journal of Intellectual Disability Research 47 (4-5): 367-384.

Poston, D., A. Turnbull, P. Jiyeon, M. Hasheem, M. Janet, and W. Mian. 2003. 'Family Quality of Life: A Qualitative Inquiry.' Mental Retardation 41 (5): 313-328.

Price, B. J., K. Y. Mayfield, A. C. McFadden, and G. E. Marsh. 2000. 'Collaborative Teaching: Special Education for Inclusive Classrooms.' Kansas City, MO: Parrot Publishing.

Rajić, M., and I. Mihić. 2015. 'Socio emocionalna posvećenost roditelja dece sa smetnjama u razvoju:razlike između majki i očeva.' Godišnjak Filozofskog fakulteta u Novom Sadu 40 (2): 137-153.

Rentinck, I., M. Ketelaar, M. Jongmans, E. Lindeman, and J. W. Gorter. 2009. 'Parental Reactions Following the Diagnosis of Cerebralpalsy in Their Young Child.' Journal of Pediatric Psychology 34 (6): 671-676.

Ristić-Stojiljković, R. 2016. 'Dečji doživljaj roditeljskog sukoba i emotivna sigurnost deteta.' Zbornik radova Učiteljskog fakulteta Užice 19 (18): 87-100.

Smith-Bird, E., and A. P. Turnbull. 2005. 'Linking Positive Behavior Support to Family Quality-of-Life Outcomes.' Journal of Positive Behavior Interventions 7 (3): 174-180.

Škrbić, R., V. Milankov, M. Veselinović, and A. Todorović. 2011. 'Uticaj oštećenja sluha na kvalitet života adolescenata.' Medicinski pregled 66 (1-2): 32-39.

Van ljzendoorn, M. H., A. H. Rutgers, M. J. Bakermans-Kranenburg, S. H. Swinkels, E. Van Daalen, C. Dietz, F. B. A. Naber, J. K. Buitelaar, and H. Van Engeland. 2007. 'Parental Sensitivity and Attachment in Children with Autism Spectrum Disorder: Comparison with Children with Mental Retardation, with Language Delays, and with Typical Development.' Child Development 78 (2): 597-608.

Waters, E., E. Maher, L. Salmon, D. Reddihough, and R. Boyd. 2005. 'Development of a Condition-Specific Measure of Quality of Life for Children with Cerebral Palsy: Empirical Thematic Data Reported by Parents and Children.' Child: Care, Health and Development 31 (2): 127-135.

\section{Kakovost življenja otrok s posebnimi potrebami v obdobju zgodnjega otroštva}

Družina predstavlja primarno družbeno skupnost, ki usmerja in spodbuja razvoj otroka, oblikuje otrokovo osebnost, usmerja njegovo udeležbo v družbi, njeno delovanje pa pomembno vpliva na kakovost življenja vseh njenih članov. Izhajajoč iz dejstva, da je vzgoja otroka z motnjami v razvoju resen izziv za starše, zahteva večjo vključenost in večjo skrb za otroke, je bil cilj te raziskave ugotoviti, v kolikšni meri prisotnost otrok s posebnimi potrebami vpliva na kakovost življenja družine. Kot napovedovalec kakovosti družinskega življenja je 
poudarjena intenzivnost vedenjskih težav pri otrokovem vedenju (fizično, čustveno, socialno in vedenje $v$ vrtcu). Raziskava je bila izvedena na vzorcu 81 staršev predšolskih otrok ( $44,4 \%$ staršev otrok s posebnimi potrebami in $55,6 \%$ staršev otrok normativnega razvoja). Mnenje staršev o intenzivnosti vedenja in vplivu kroničnega stanja otroka na življenje njihovih družin smo pridobili z vprašalnikom generičnega tipa PedsQL - dejavnik družinskega vpliva. Raziskava je potrdila, da prisotnost posebnih potreb in specifičnega vedenja otrok vpliva na delovanje družine in da se kakovost življenja le-te bistveno razlikuje od družin z otroki normativnega razvoja razvoja.

Ključne besede: družina, kakovost življenja družine, starši invalidnih otrok, otrok s posebnimi potrebami, tipično razviti otroci 